\title{
Mental health of young Brazilians: Barriers to professional help-seeking
}

\author{
Saúde mental de jovens brasileiros: barreiras \\ à busca por ajuda profissional
}

\author{
Cláudia Cristina FUKUDA ${ }^{1}$ \\ Maria Aparecida PENSO ${ }^{2}$ \\ Deise Matos do AMPARO $^{3}$ \\ Bruno Coimbras de ALMEIDA ${ }^{4}$ \\ Camila de Aquino MORAIS ${ }^{3}$
}

\begin{abstract}
The present study investigated the perception of young Brazilians of professional help and barriers to seeking mental health services. A total of the 1,030 questionnaires were administered to young people aged 8-21 years of both genders attending public and private school or who had received or were receiving treatement at mental health facilities in three Brazilian cities. The data were evaluated using descriptive statistics, exploratory factor analysis, and comparison between means. The results showed fear of stigmatization as a major barrier to seeking mental health treatment, exerting greater impact than that of structural barriers. Regional differences influenced their perception of the treatment. Having undergone previous mental health treatment was found to be related to a greater perception of the positive effects of the treatment and the structural barriers to accessing care services. It was found that the onset of mental disorders usually occurs during early adolescence. School-related issues, anxiety, fear, and depression were the most common reasons for mental health treatment seeking among young people.
\end{abstract}

Keywords: Adolescent; Mental health; Mental health services; Therapeutics.

\section{Resumo}

A presente pesquisa investigou a percepção de jovens brasileiros sobre ajuda profissional e barreiras na busca de serviços em saúde mental. Foram aplicados 1030 questionários em jovens com idade entre 8 e 21 anos, de ambos os

$\nabla \nabla \nabla$

1 Universidade Católica de Brasília, Escola de Saúde, Programa de Pós-Graduação Stricto Sensu em Psicologia. Campus Avançado Asa Norte, SGAN 916, Módulo B, Avenida W5, Sala A203, 70790-160, Brasília, DF, Brasil. Correspondência para/Correspondence to: C.C. FUKUDA. E-mail: <fukuda@ucb.br>.

2 Universidade Católica de Brasília, Curso de Psicologia, Programa Pós-Graduação Stricto Sensu em Psicologia. Brasília, DF, Brasil.

3 Universidade de Brasília, Instituto de Psicologia, Departamento de Psicologia Clínica. Brasília, DF, Brasil.

${ }^{4}$ Universidade Católica de Brasília, Curso de Psicologia. Brasília, DF, Brasil.

Support: Conselho Nacional de Desenvolvimento Científico e Tecnológico and Fundação de Apoio a Pesquisa do Distrito Federal developed under the project "Concepções de saúde e doença mental na perspectiva de jovens e cuidadores" adapted for Brazil from the project "Access to Mental Health Care in Children", coordinated by Cristhoph Kappler. 
sexos, em três capitais brasileiras, de escolas e serviços de saúde mental públicos e privados. Foram realizadas estatísticas descritivas e inferenciais, comparação entre médias e análise fatorial exploratória. Os resultados demonstraram o medo do estigma como barreira na busca de tratamento em saúde mental, tendo maior impacto que as barreiras estruturais. Diferenças regionais influenciaram a percepção sobre o tratamento. Experiência anterior com tratamento em saúde mental relacionou-se a uma maior percepção dos efeitos positivos do mesmo e das barreiras estruturais para acesso aos serviços. Identificou-se maior incidência de adoecimento mental no início da adolescência. Problemas na escola, ansiedade, medo e depressão foram os problemas mais comuns relacionados à busca de tratamento em saúde mental.

Palavras-chave: Adolescente; Saúde mental; Serviços de saúde mental; Terapêutica.

Adolescence is a period of physical and psychosocial changes, which is sometimes accompanied by feelings of uncertainty and insecurity. It is a period of increased vulnerability and risk mental disorders, such as depression, conduct and eating disorders, and drugs and violence (Benetti, Ramires, Schneider, Rodrigues, \& Tremarin, 2007).

According to the World Health Organization, around $20 \%$ of the world's children and adolescents have mental disorders; out of which 4 to $6 \%$ require clinical intervention. Only one-third of all countries that participated in the survey on mental health of children and adolescents conducted by the World Health Organization in 2005, had mental health services specifically for children and adolescents (World Health Organization, 2005).

Mental health issues affect all age groups; however, there is an increasing need to investigate the risk factors in adolescents. In Brazil, the number of scientific publications on mental health has been growing steadly since 2007 (Pinto et al., 2014).

Fleitlich and Goodman (2001) point out the prevalence of mental disorders in $12.7 \%$ of children aged 7-14 years. This result should be viewed with caution since in Brazil and some other countries, particularly in less developed countries, the lack of human resources and priority and weaknesses in the mental health services make it difficult to obtain reliable data on the state of the mental health of adolescents (Assis, Avanci, Pesce, \& Ximenes, 2009). The indentification of issues and factors associated with the etiology of adolescent psychopathology and the identification of barriers to accessing mental health services can help preventing mental illnesses
Adolescents that do not receive treatment for mental health problems are more likely to have lower school performance and engage in criminal behavior and are more vulnerable to unemployment, drug use, poor sexual and reproductive health, self-harm, and inadequate self-care (Brasil, 2010). A study on the perceptions of young Brazilians about health and mental illness found that mental disorder was characterized as an emotional disorder related to internal and relational experiences (Morais, Amparo, Fukuda, \& Brasil, 2012).

Given this reality, actions to promote mental health and the prevention and treatment of problems that commonly arise during the adolescent years can contribute to reduce the load on the health care systems (Fisher et al., 2011).

This study seeks to contribute to research in the filed by assessing young people's perception of mental health illness and treatment, considering those with and without experience in Psychological and/or Psychiatric Treatment (P/PTr). This study aims to: identify mental health problems and barriers to mental health treatment encountered by young people; compare the barriers reported by children and adolescents with and without experience in Psychological and/or Psychiatric Treatment in three Brazilian cities; and to report their perceptions of the treatment experience or possible treatment experience.

\section{Children and adolescents' mental health care in Brazil}

Historically, mental health problems in childhood and adolescence have not been a major mental health policy priority in Brazil. The gap left 
by lack of sufficient public health care for this population has been filled by private and philanthropic sectors and health care service centers that commonly offered treatments that include hospitalization and isolation from family and community.

Since the 1990s, a psychiatric reform movement has pointed out the need for the development of child and adolescent mental health care policies. During the $2^{\text {nd }}$ National Conference on Mental Health, held in 1992, the perverse effects of the institutionalization of children and youth were demonstrated, and during the $3^{\text {rd }}$ National Conference on Mental Health in 2001, it was determined that government action plans for the implementation of a new model of care and treatment to children and adolescent would not be postponed (Brasil, 2005b).

In August 2004, through decree $n^{\circ} 1608$, the Ministry of Health approved the National Forum on Children Mental Health aiming at the development of proposals and policies for the consolidation of the field of mental health for these subjects (Brasil, 2004). In 2005, the Forum disseminated the first guidelines for the deinstitutionalization and the develoment of a community-based child and adolescense mental health care system based on the logic of psychosocial care. Accordingly, the consolidation and expansion of Child and Youth Mental Health Services (CAPSi, Centros de Atenção Psicossocial infanto-juvenil Child and Youth Psycosocial Care Centers) and health care services for psychologically disturbed children and adolescents is essential for changing the mental health status of children and adolescents (Brasil, 2005b).

Despite these efforts, with respect to the development of public policies aimed at children and adolescents, there is a lot still to be done in terms of opening new CAPSi and raising health network awareness, especially Primary Care, in which the risk factors for mental health problems in this age group need to be identified thus ensuring appropriate referrals and the implementation of prevention programs. The integration of mental health services with other professional fields and services, such as social assistance and education, and child protection agencies is extremenly important to enable the building and implementation of a network of care and protection (Assis et al., 2009).

As Benetti et al. (2007) emphasized, interventions in mental health in adolescence are focused on rehabilitation in which treatment is restricted to the most severe cases only, but it is necessary to consolidate knowledge regarding interventions, illness prevention, and models encompassing contextual and macro aspects of the understanding of mental health, such as resilience and individual, family, and collective health.

\section{Barriers to mental health care access}

The World Health Organization (2005) reported a number of barriers to accessing mental health services in several countries. The lack of resources has been identified as a universal problem. In low-income countries, the lack of affordable transportation was considered the most significant barrier and, in high-income countries, stigma was identified as the most significant barrier.

Owens et al. (2002) pointed to three types of barriers to mental health treatment in children and adolescents: structural barriers (long waiting lists, inability to pay for services, transportation problems, etc.); barriers related to perceptions of mental health problems (inability for parents, teachers, and care providers to identify the need for treatment or deny the severity of a mental problem, and belive in order to deal with the problem without treatment; and barriers related to perceptions of mental health services (lack of confidence or negative experience with a previous service in mental health, and stigma related to receiving care). Owens et al. (2002) found that one third of the parents surveyed reported barriers to mental health services; of which, $25.9 \%$ indicated these barriers were related to perceptions of mental health services, $23.3 \%$ to perceptions of mental problems, and $20.7 \%$ indictated they were structural barriers. Other studies described similar barriers to children's mental health services (Couto, Duarte, \& Delgado, 2008; Flavina \& Cerqueira, 2008). 
There is still a lot social prejudice surrounding the mental health care of children and adolescents and other age groups, which is held by the children and adolescentes themselves and is also seen within health. The lack of knowledge in the general public and health professionals about the particularities of mental health care can be identified as a factor that contributes to the stigma associated to mental illness (Simões, Fernandes, \& Aiello-Vaisberg, 2013).

\section{Method}

\section{Participants}

A total of 1,030 children and adolescents from three different Brazilian cities participated in the present study. The cities included Brasilia (56.4\%), Porto Alegre (33.9\%), and Belém (33.9\%). The majority of the participants (children and adolescents) were public school students (46.1\%), followed by private school students (35.0\%) and others who had received or were receiving care and treatment at public $(4.7 \%)$ or private health care centers (14.2\%). The schools and health centers were selected based on convenience sampling, and the data were collected between 2009 and 2010 .

The age of the participants ranged from 8 to 21 years (Mean - $M=15.3$; Standard Deviation $S D=1.8$ ). The children and adolescents from Brasilia were older $(M=16.2 ; S D=1.5)$, followed by those from Porto Alegre $(M=14.6 ; S D=1.4)$ and Belém $(M=13.7 ; S D=2.1)(F[2,1107]=118.1 ; p<0.001)$. Girls and young women made up $52.4 \%$ of the sample. Most children and adolescents were attending high school (52.4\%), 37.4\% were in middle and school, and $10.1 \%$ did not provide school level information.

Most participants reported that they had never received care/treatment for mental health/ emotional problems (P/PTr) (61.0\%); 38.2\% (393 participants) reported that they had already received or were undergoing treatment (P/PTr), and $0.9 \%$ did not answer. Of the 393 children and adolescents who had received P/PTr, $45 \%$ were from Brasília,

\section{Instruments}

The mental health questionnaire used was adapted from the Swedish version (Käppler, 2004). The cross-cultural adaptation of the instrument was described by Aquino-Morais (2014) and was based on a model with complex procedures (Reichenheim \& Moraes, 2007), whose premise is that the constructs under study are not the same across cultures (Herdman, Fox-Rushby, \& Badia, 1998). The analysis to verify the equivalence between the original and adapted instrument includes six dimensions: conceptual equivalence, item, semantic, operational, measurement, and functional (Aquino-Morais, 2014).

The $\mathrm{G}$ and $\mathrm{H}$ questions of the questionnaire were analyzed. The $\mathrm{G}$ question refers to the reasons why the participants did not want to seek psychologist/psychiatrist couseling (four-point Likert-type scale). The $\mathrm{H}$ question refers to health service use report indicating whether the participants had received professional help for mental health problems. It consisted of six questions that were answered only by those who had received treatment (type of problem, speciality of the health professional, age at onset of problem, and treatment and after treatment).

\section{Procedures}

Different procedures for data collection in schools and health facilities were used. The schools were selected according to the following criteria: (a) private schools located in a region with high Human Development Index (HDI) and public schools located in a region with low HDI (Programa das Nações Unidas para o Desenvolvimento, 2010); and (b) access to researchers. The researchers were allowed to collect data in the schools after the approval of the research proposal. The questionnaire was administered in one to two randomly selected classrooms. Prior to initiating data collection, written informed consent was requested of parents and adolescentes. In the health facilities (public or private), the caregivers were initially invited to participate in the study, the research purposes were 
explained, and their consent was requested. Subsequently, the questionnaire was administered individually to the children and adolescents who had agreed to participate. The present study was approved by the Research Ethics Committee of the Universidade Católica de Brasília (Catholic University of Brasilia) (Process/UCB 86/2006).

\section{Results}

Data were evaluated using descriptive statistics for the determination of means and frequencies. Chi-square, $t$ tests, and analysis of variance were used for comparison between groups, at a significance level of 0.05. Exploratory Factor Analysis and Internal Consistency were used to evaluate the answers to the questions on barriers to mental health care.

Considering only the participants who had received or were undergoing P/PTr, the analysis focused on identifying the type of problems the participants faced receiving professional help. A total of 466 problems were reported. School-related issues were the most commonly reported problem, followed by anxiety, depression, and fear. Behavioral issues and relationship problems with family and friends were the third most commonly reported problems. There were significant differences between the cities investigated in the following issues: (a) depression: there was a higher incidence in Brasilia and Belém; (b) family problems: higher incidence in Porto Alegre and lower incidence in Belém; (c) emotional problems: higher incidence in Porto Alegre (Table 1).

Gender also influenced the occurrence of the problems reported. The girls reported a higher frequency of anxiety $\left(\chi^{2}=5.4 ; p<0.05\right)$ fear $\left(\chi^{2}=8.7 ; p<-0.005\right)$, and depression $\left(\chi^{2}=4.5\right.$; $p<0.05)$. On the other hand, the boys reported more school-related problems $\left(\chi^{2}=3.7 ; p<0.10\right)$.

Only $282(72.0 \%)$ children and adolescents who received P/PTr provided information about the speciality of the health professionals who helped them; psychologist (57.2\%) was the most commonly reported. Psychiatrist was reported only by 26 (6.6\%) of the participants, psychologist and psychiatrist was reported by 17 (4.3\%) participants, and other professionals was reported by $14(3.6 \%)$ participants. It was found that the participants from Belém had the highest rate of reports of other professionals $\left(\chi^{2}=59.5 ; p<0.001\right)$.

Table 1

Prevalence of mental problems in young people who had received professional help by city surveyed. Brazil, 2009-2010

\begin{tabular}{|c|c|c|c|c|c|c|c|c|c|}
\hline \multirow{2}{*}{ Reasons for mental health treatment } & \multicolumn{2}{|c|}{ Brasilia } & \multicolumn{2}{|c|}{ Porto Alegre } & \multicolumn{2}{|c|}{ Belém } & \multicolumn{2}{|c|}{ Total } & \multirow[b]{2}{*}{$\chi^{2}$} \\
\hline & $\mathrm{n}$ & $\%$ & $\mathrm{n}$ & $\%$ & $\mathrm{n}$ & $\%$ & $\mathrm{n}$ & $\%$ & \\
\hline School- related problems including learning disabilities. & 51 & 21.9 & 24 & 16.9 & 17 & 18.9 & 92 & 19.7 & ns \\
\hline Anxierty/nervousness. & 38 & 16.3 & 22 & 15.4 & 8 & 8.9 & 68 & 14.6 & ns \\
\hline Depression/death-wish. & 33 & 14.1 & 7 & 4.9 & 22 & 24.4 & 62 & 13.3 & $18.8^{* *}$ \\
\hline Fear. & 23 & 9.9 & 24 & 16.8 & 10 & 11.1 & 57 & 12.2 & ns \\
\hline Family problems. & 22 & 9.4 & 26 & 18.2 & 3 & 3.3 & 51 & 10.9 & $14.5^{* *}$ \\
\hline Behavorial problems. & 22 & 9.4 & 10 & 7.0 & 11 & 12.2 & 43 & 9.2 & ns \\
\hline Relationship problems with friends/ classmates and boyfriend/girlfriend. & 17 & 7.3 & 11 & 7.7 & 6 & 6.7 & 34 & 7.3 & ns \\
\hline Mental disorder (OCD, psychosis, ADHD, eating disorders etc.). & 9 & 3.9 & 4 & 2.8 & 6 & 6.7 & 19 & 4.1 & ns \\
\hline Unspecified emotional and personal problems, physical health, and stress. & 3 & 1.3 & 9 & 6.3 & 3 & 3.3 & 15 & 3.2 & $7.0^{*}$ \\
\hline Alcohol and drug problems. & 5 & 2.1 & 1 & 0.7 & 1 & 1.1 & 7 & 1.5 & - \\
\hline Others (professional choices, low self-esteem etc.). & 6 & 2.6 & 5 & 3.5 & 3 & 3.3 & 14 & 3.0 & - \\
\hline Don't know or don't remember. & 4 & 1.7 & - & - & - & - & 4 & 0.8 & - \\
\hline Total & 233 & 50.0 & 143 & 30.7 & 90 & 19.3 & 466 & 100.0 & \\
\hline
\end{tabular}

Note: ${ }^{*} p<0.05 ;{ }^{* *} p<0.001$.

ns: not significant; - : Analysis not performed, insufficient n; OCD: Obsessive-Compulsive Disorder; ADHD: Attention-Deficit/ Hyperactivity Disorder. 
The mean age of the participants at onset of the problem was 10.6 years $(S D=3.4)$. The most common age at onset of the problem was between 6-9 (21.5\%) and $10-13$ years old (32.7\%), which corresponds to literacy and puberty, respectively. Only 17 (3.4\%) participants were less than six years old when the problem started, $70(17.1 \%)$ were between 14 and 18 years old, and $22.4 \%$ did not report when the problem started. The mean age at the beginning of treatment was 11.8 years old $(S D=3.3)$. A total of $35.9 \%$ of participants' treatment began in the same year that the problem was identified, 7 participants (1.7\%) reported that treatment began before the onset of the problem, and $39.3 \%$ reported that the treatment began almost a year after the onset of the problem. Among the children and adolescents who had received P/PTr, 43.4\% reported they had completed the treatment 3.4 years earlier, on average $(S D=2.9)$.

The participants from Porto Alegre were younger when the problem started $(M=9.5$, $S D=3.2)$ than those from Brasilia $(M=10.7$, $S D=3.4)$ and Belém $(M=12.1, S D=3.0)$, and, in addition, there were significant differences between them $(F[2.309]=11.98 ; p<0.001)$. The same pattern was observed at the beginning of treatment; the mean age of the participants from Porto Alegre $(M=10.5, S D=3.2)$ was lower than that of participants from Brasilia ( $M=11.9 ; S D=3.3)$ and Belém $(M=13.1, S D=2.6)$. There was significant difference between the two latter groups too $(F[2.307]=136.8 ; p<0.001)$. There were no significant differences in the treatment completion time.

\section{Perceptions of treatment}

The participants who had received, had not received, or were receiving $\operatorname{TrP} / \mathrm{P}$ were asked about various aspects of treatment. The items 'therapy helps', 'feel comfortable with the therapist', 'therapy promotes stability' and 'can express their own opinion'showed significant differences in the cities surveyed $(F=5.61 ; p<0.005 ; F=9.16 ; p<0.001$, $F=12.82, p<0.001$ and $F=10.46, p<0.001$, from Belém regarding their agreement with the statements 'therapy helps', 'feel comfortable with the therapist', 'therapy promotes stability and support' were significantly higher than those given by the participants from Brasilia and Porto Alegre. The scores given by children and adolescents from Porto Alegre regarding the statement 'can express their own opinion' were also significantly higher than those given by the participants from Brasilia.

The perceptions of the participants who had and those who had not received P/PTr were analyzed separately by city. It was observed that, in the three cities, those who had received P/PTr tended to agree more with the statement about feeling comfortable with the therapist. As for the statement 'therapy helps', the average score of the participants who had received P/PTr was higher than that of those who had not received it, only for the participants from Belém. The participants from Brasilia and Belém who had had experience with P/PTr agreed that therapy promotes more stability, security, and support. The participants from Brasilia who had received or were receiving P/PTr showed the highest rate of agreement with the statement regarding being able to express their own opinion in therapy. On the other hand, the children and adolescents from Brasilia and Porto Alegre who had not received P/PTr agreed that more people frown, looking at them with disapproval when they are at a doctor's office or health center (Table 2). There was no association between location and treatment.

\section{Barriers to mental health treatment}

A set of 15 barriers to seeking P/PTr were reported by the children and adolescents. Factor analysis using the Principal Axis Factoring (PAF) and the oblique rotation (Direct Oblimin) method was performed to verify whether this set of barriers could be explained by a smaller number of hypothetical variables (factors) (Pasquali, 2012). The KaiserMeyer-Olkin (KMO) measure of sampling adequacy was 0.861 , indicating that the data were appropriate for factor analysis. The three factor-solution was considered the best factor solution by the Horn's Parallel Analysis (Pasquali, 2012), explaining 47.6\% 
Table 2

Perceptions of treatment among young people with and without experience in Psychological or Psychiatric Treatment (P/PTr) by city surveyed. Brazil, 2009-2010

\begin{tabular}{|c|c|c|c|c|c|c|c|}
\hline \multirow{2}{*}{ Perception } & \multirow{2}{*}{ P/PTr } & \multicolumn{2}{|c|}{ Brasilia } & \multicolumn{2}{|c|}{ Porto Alegre } & \multicolumn{2}{|c|}{ Belém } \\
\hline & & M & $S D$ & M & $S D$ & M & $S D$ \\
\hline \multirow[t]{2}{*}{ Therapy helps. } & Received & 2.56 & 0.94 & 2.97 & 0.94 & 3.30 & 0.85 \\
\hline & Did not receive & 2.80 & 0.92 & 2.88 & 0.87 & 2.92 & $0.82^{*}$ \\
\hline \multirow[t]{2}{*}{ Felt/feel confortable with the therapist. } & Received & 2.56 & 1.11 & 2.63 & 0.98 & 2.97 & 0.99 \\
\hline & Did not receive & 2.12 & $0.93^{* \star *}$ & 2.21 & $0.91^{* * *}$ & 2.22 & $0.88^{* * *}$ \\
\hline \multirow[t]{2}{*}{ Did not accept/accepted the therapy at first. } & Received & 2.12 & 1.14 & 2.13 & 1.08 & 2.20 & 1.16 \\
\hline & Did not receive & 1.83 & $0.93^{* *}$ & 2.00 & 1.03 & 1.83 & 1.05 \\
\hline \multirow[t]{2}{*}{ Therapy promotes stability, security, and support. } & Received & 2.58 & 1.07 & 2.64 & 0.96 & 3.13 & 0.87 \\
\hline & Did not receive & 2.35 & $1.00^{*}$ & 2.51 & 0.97 & 2.63 & $1.00^{*}$ \\
\hline \multirow[t]{2}{*}{ Ability to express their own opinion in therapy. } & Received & 2.89 & 1.00 & 2.91 & 0.92 & 3.08 & 0.88 \\
\hline & Did not receive & 2.59 & $1.01^{* *}$ & 2.93 & 0.92 & 3.03 & 0.79 \\
\hline \multirow{2}{*}{$\begin{array}{l}\text { Disapproving look from people seeing them at doctor's office } \\
\text { or health center. }\end{array}$} & Received & 1.61 & 0.94 & 1.65 & 0.91 & 1.72 & 1.01 \\
\hline & Did not receive & 1.85 & $1.02^{*}$ & 1.87 & $1.03^{*}$ & 1.91 & 0.92 \\
\hline
\end{tabular}

Note: ${ }^{*} p<0.05 ;{ }^{* *} p<0.005 ;{ }^{* * *} p<0.001$.

M: Mean; SD: Standard-Deviation.

of the total variance. Two items did not load onto any factor.

The first factor had an Eigenvalue of 3.13 after rotation and internal consistency (Cronbach's Alpha) of 0.77 . This factor was composed of six items with fator loading between 0.42 and 0.77 . These items indicated stereotypes about people with mental health treatment and the consequences for their lives and was denominated fear of stigmatization.

The Eigenvalue of the second factor was 2.74, and the Cronbach's Alpha was 0.69. This factor was composed of five items with factor loadings ranging between 0.46 and 0.66 . The items were related mainly to barriers associated with the minor importance given to mental illness and its treatment, refusal to recognize the problem, and the lack of information about treatments; therefore, it was denominated problem denial.

The last factor was composed of only three items with factor loadings ranging between 0.41 to 0.67, Eigenvalue of 3.01, and low internal consistency $(\alpha=0.66)$. These items characterized the barriers to accessing mental health services and to the continuity of treatment and were therefore considered external barriers; the factor was denominated structural barriers.

The factor that had the highest mean for participants that had received or were receiving and those who had not received P/PTr was fear of stigmatization $(M=2.50 ; S D=0.73$ and $M=2.50$; $S D=0.77$, respectively), followed by the factor mental problem denial $(M=2.22 ; S D=0.64$ and $M=2.22 ; S D=0.67)$ and the factor structural barriers $(\mathrm{M}=1.99 ; \mathrm{SD}=0.80$ and $\mathrm{M}=1.84$; $S D=0.72$ ). Significant difference was found in the factor structural barriers between the means of the two groups, the participants who had received P/PTr had a mean value higher than that of the participants who had not received $\mathrm{P} / \mathrm{PTr}(t=3.21$; $p<0.001)$.

Significant differences were also identified in the factor fear of stigmatization between the cities Brasilia and Porto Alegre ( $F$ [999:2] = 4.65; $p<0.05)$ and in the factor structural barriers $(F[2,989]=8.96 ; p<0.001)$ among Porto Alegre and Brasilia and Belém. Thus, the participants from Porto Alegre showed, on average, less fear of stigmatization $(M=2.39, S D=0.71)$ than those from Brasilia $(M=2.54, S D=0.80)$, and they had lower structural barriers average $(M=1.77, S D=0.66)$ 
than those from Brasilia $(M=1.94, S D=0.79)$ and Belém $(\mathrm{M}=2.09, \mathrm{SD}=0.81)$.

An association effect in terms of the factor problem denial indicates that there was an increase in the mean of this barrier in Brasilia and Belém for the participants who had received or were receiving P/PTr and a decrease in the mean for the participants from Porto Alegre, (Figure 1). There was no effect of interactions for the factors fear of stigmatization and structural barriers.

\section{Discussion}

The children and adolescents showed a relatively low level of agreement with the barriers associated to P/PTr, and the highest level of agreement was with the barriers associated to mental disorder stereotypes. Therefore, according to the young people surveyed, the prejudice against people with mental disorders is a major barrier to accessing heath care services. This result is in accordance with those of Simões et al. (2013), who

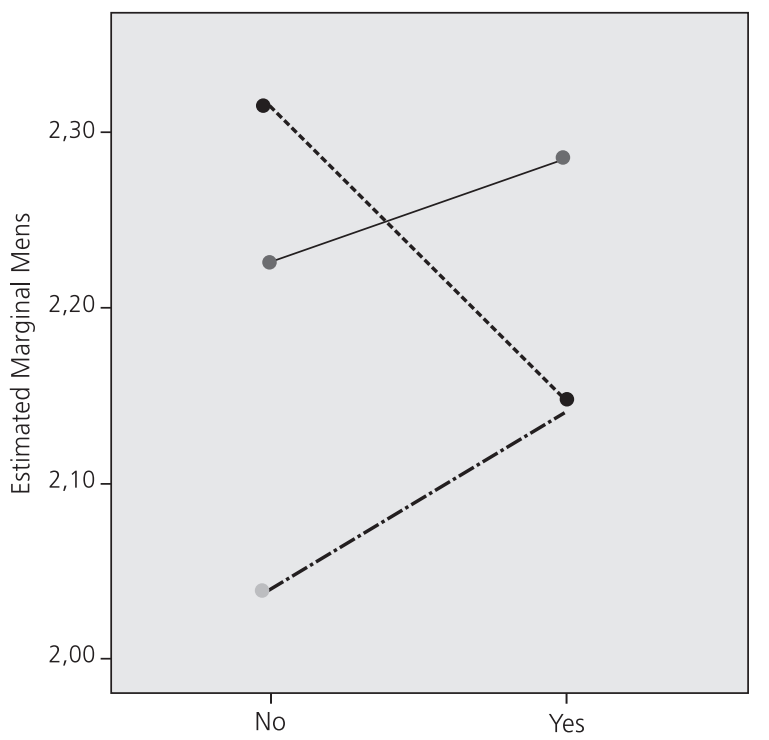

Received psychological or psychiatric treatment

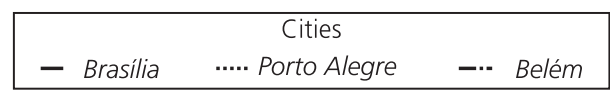

Figure 1. Interaction between city and Psychological and/or Psychiatric Treatment for the factor problem denial. found that changes in policies for mental health services and greater availability of services are insufficient to overcome the prejudice about mental ilness. Identifying stigma as a major barrier faced by young people seeking out mental health treatment demonstrates that there is a lot still to be done in terms of overcoming the discrimination against users of mental health services in Brazil.

The factor structural barriers had the lowest agreement rate between the young people surveyed; therefore, aspects related to access to mental health services, financial conditions, and means of transport were not considered major obstacles to help seeking. Owens et al. (2002) also found that structural barriers were less commonly reported than the barriers associated with the quality of services provided and the perception of mental illness. However, it can be said that the low level of internal consistency may have influenced the outcomes.

There was a greater perception of structural barriers to accessing treatment in young people who had already had mental health treatment. Some studies reported an association between structural barriers and access of services. These barriers included ease or difficulty in access to health care services (Flavina \& Cerqueira, 2008), long waiting lists, problems with transportation, and inability to pay (Owens et al., 2002; World Health Organization, 2005). Thus, experiences with mental health care may have increased awareness about the difficulties in access to services, confirming that structural barriers are a possible obstacle to help seeking and continuity of P/PTr.

It was found that having received P/PTr did not reduce the perception of barriers associated with fear of stigmatization and problem denial. These barriers are probably associated with cultural factors; this assumption is verified by the differences found between the Brazilian cities investigated, such as the perception of the three types of barriers analyzed. Nevertheless, it was observed that the participants who had received treatment reported that the therapy helped and that they felt comfortable with the therapist, evaluating the 
treatment positively. These findings may show that macro-social issues, such as prejudice, may influence care seeking, especially when there is high prevalence of anxiety, depression, and fear and these were the problems that motivated young people to seek P/PTr. These findings corroborate Benetti et al. (2007) since they show that the mental health rehabilitation of adolescencents is more commonly based on seeking P/PTr than on prevention actions.

In the present study, it was found that the onset of mental disorders occured between 10 and 13 years old, early adolescence; a period when there is higher risk of developing mental ilnesses such as depression, conduct disorder, eating disorders, and violent behavior (Benetti et al., 2007). Therefore, primary care services for this age group should ensure the provision of effective early interventions to reduce iatrogenic risks.

The major problem identified among young people seeking P/PTr was school-related problems, followed by anxiety, fear, and depression. Behavioral issues and family and friends' issues were the third most commonly problems identified. This finding is consistent with previous studies that identified school-related problems, anxiety, and depression as the main problems that lead people to seek P/PTr (D'Abreu \& Maturano, 2011; Ramires, Passarini, Flores, \& Santos, 2009).

The high prevalence of school-related problems as one of the major factors for seeking mental health treatment is an important aspect to be analyzed because it involves integrating mental health with the school system and the community in terms of primary mental health care. It is important to mention that the school, which should be a member of the physical and mental health care network, can be a place for reception and referral to primary health care, which can be done through the Programa Saúde na Escola (School Health Program), developed in 2007, which among other things, aims at the support of public school students' health (Brasil, 2007).

The integration of school with primary health care enables an early diagnosis of children and adolescents' mental health problems. Primary care has a major role in ensuring access to appropriate health services and stigma reduction and provides entry into the health system (Brasil, 2013). According to Brazilian Law, in order for primary care providers to offer appropriate services, they must be interconnected, they should work in collaboration with the Núcleo de Apoio a Saúde da Familia (NASF, Family Health Support Center), which is responsible for such integration (Brasil, 2008).

Implementing a care network including primary care, such as Unidades Básicas de Saúde (UBS, Primary Care Health Units), and high- complexity care services is extremely important in order to ensure that the CAPSi do not have the sole responsibility for mental health care of this population. Therefore, the provision of a comprehensive and integrated mental health care for young people can lessen difficulties related to structural barriers, fear of stigmatization, and problem denial.

There were regional differences in the age at the onset of the problem and benginning of treatment. These differences may be due to the age of the participants from Brasilia and Porto Alegre; however, Belém had the youngest participants and the highest average age at the onset of problems and the earliest treatment beginning. This highlights the importance of carrying out regional difference analyses in mental health research.

Fear of stigmatization was found to be a major barrier to seeking P/PTr, exerting greater impact than than that of structural barriers. However, having undergone P/PTr was found to be related to a greater perception of the positive effects of the treatment. It was also observed that early adolescence is the most common period for the emergence of mental illness, and that school-related problems, anxiety, fear, and depression are the most common reasons that led young people to seek P/PTr.

Although the results of the barriers to mental health obtained in this study used barriers described by Swiss youths, there was consistency with the results found by other authors using Brazilian population (Assis et al., 2009; Fleitlich \& Goodman, 
2001; Santos, 2006). Further research is suggested on the mapping of barriers to seeking P/PTr allowing a more thorough characterization of mental ilness stigma. It can be said that schools are an important setting for assessing the mental health of adolescents and children.

In general, the young people surveyed considered fear of stigmatization as the major barrier to seeking P/PTr. The lack of information about mental illness and virtually no public policies for social inclusion of people with mental disorder, as well as historical context and cultural aspects of mental illness, are factors that reinforce the maintenance of these stigmas. Although the Psychiatric Reform has made a series of changes in the practices, knowledge, cultural and social values of health care providers, services, and relationships (Amarante, 2003; Brasil, 2005a; Furtado \& Campos, 2005), the survey data indicated that the stigma of mental ilness is a major factor contributing to barriers to the access of health care.

The concept of illness and psychological distress related to the paradigm of insanity was found to be a stereotype of participants. Mental illness stigma is related to the paradigm of social exclusion and medicalization. On one hand, the stigma is seen as a barrier to accessing mental health care; on the other hand, problem denial is a factor that can also affect the perception of young people and their families of care need.

Furthermore, the differences between the cities surveyed in terms of barriers to seeking P/PTr demonstrate the particularities of each region. Accordingly, it can be said that the conceptions of mental health and barriers to accessing care services are influenced by contextual, family, and individual factors. Educational campaigns to mobilize and promote the integration of adolescents aiming at responsibility and recognition of the role of young people, devoting closer attention, and promoting health including the family, the school and the community, and the effectiveness of primary care policies for mental health are key factors for overcoming these barriers.

The target group of the survey included

364 young people from three different cities; however, more data are needed to better characterize Brazilian young people by including children and adolescents from other regions and non-urban areas. It is worth mentioning the importance of identifying cultural factors that affect the perception of barriers to mental health treatment for young Brazilians.

\section{Contributors}

All authors equally contributed to the conception and design of this study, data analysis and interpretation, discussion of the results, and review and final approval of the manuscript.

\section{References}

Amarante, P. (2003). A (clínica) e a reforma psiquiátrica. In P. Amarante (Ed.), Archivos de saúde mental e atenção psicossocial. Rio de Janeiro: Nau.

Aquino-Morais, C. (2014). Concepções de saúde e doença mental: adaptação transcultural e evidências de validade do instrumento acesso aos cuidados em saúde mental (Tese de doutorado não-publicada). Universidade de Brasília.

Assis, S. G., Avanci, J. Q., Pesce, R. P., \& Ximenes, L. F. (2009). Situação de crianças e adolescentes brasileiros em relação à saúde mental e à violência. Ciência \& Saúde Coletiva, 14(2), 349-361.

Benetti, S., Ramires, V. R. R., Schneider, A. C., Rodrigues, A. P. G., \& Tremarin, D. (2007). Adolescência e saúde mental: revisão de artigos brasileiros publicados em periódicos nacionais. Cadernos de Saúde Pública, 23(6), 1273-1282.

Brasil. Ministério da Saúde. (2004). Portaria n 1.608, de 3 de agosto de 2004. Constitui Fórum Nacional sobre Saúde Mental de Crianças e Adolescentes. Recuperado em janeiro 9, 2015, de http://bvsms.saude.gov.br/bvs/ saudelegis/gm/2004/prt1608_03_08_2004.html

Brasil. Ministério da Saúde. (2005a). Reforma psiquiátrica e política de saúde mental no Brasil. Documento apresentado à Conferência Regional de Reforma dos Serviços de Saúde Mental: 15 anos depois de Caracas. Recuperado em janeiro 9, 2015, de http://bvsms. saude.gov.br/bvs/publicacoes/Relatorio15_anos_ Caracas.pdf

Brasil. Ministério da Saúde. (2005b). Caminhos para uma política de saúde mental infanto-juvenil. Recuperado em janeiro 9, 2015, de http://bvsms.saude.gov.br/bvs/ publicacoes/05_0887_M.pdf

Brasil. Presidência da República. (2007). Decreto n 6.286, de 5 de dezembro de 2007. Institui o Programa Saúde 
na Escola. Recuperado em dezembro 18, 2014, de http://bvsms.saude.gov.br/bvs/publicacoes/dec_6286_ 05122007.pdf

Brasil. Ministério da Saúde. (2008). Portaria $n^{\circ} 154$, de 24 de janeiro de 2008. Cria os Núcleos de Apoio à Saúde da Família - NASF. Recuperado em janeiro 9, 2015, de http://bvsms.saude.gov.br/bvs/saudelegis/ gm/2008/prt0154_24_01_2008.html

Brasil. Ministério da Justiça. (2010). Prevenção ao uso indevido de drogas: capacitação para conselheiros e lideranças comunitárias ( $3^{a}$ ed.). Brasília: Secretaria Nacional de Políticas sobre Drogas.

Brasil. Ministério da Saúde. (2013). Saúde mental. Brasília: Autor. (Cadernos de Atenção Básica, n 34).

Couto, M. C., Duarte, C. S., \& Delgado, P. G. (2008). A saúde mental infantil na saúde pública brasileira: situação atual e desafios. Revista Brasileira de Psiquiatria, 30(4), 384-389.

D'Abreu, L. C. F., \& Maturano, E. M. (2011). Identificação de problemas de saúde mental associados à queixa escolar segundo o DAWBA. Psico, 42(2), 152-158.

Fisher, J., Cabral, M. M., Izutsu, T., Vijayakumar, L., Belfer, M., \& Omigbodun, O. (2011). Adolescent mental health in resource-constrained settings: A review of the evidence of the nature, prevalence and determinants of common mental health problems and their management in primary health care. International Journal of Social Psychiatry, 57(5), 9-116.

Flavina, O. P., \& Cerqueira, M. B. (2008). Saúde mental infanto-juvenil: usuários e suas trajetórias de acesso aos serviços de saúde. Revista Espaço para a Saúde, 10(1), 34-46.

Fleitlich, B., \& Goodman, R. (2001). Social factors associated with child mental health problems in Brazil: Cross sectional survey. British Medical Journal, 323, 599-600.

Furtado, J. P., \& Campos, R. O. (2005). A transposição das políticas de saúde mental no Brasil para a prática nos novos serviços. Revista Latinoamericana de Psicopatologia Fundamental, 8(1), 109-122.

Herdman, M., Fox-Rushby, J., \& Badia, X. (1998). A model of equivalence in the cultural adaptation of HRQol instruments: The universalist approach. Quality of Life Research, 7(4), 323-335.

Käppler, C. (2004). Access to mental health care in children: The AMHC-Study. Concepts of mental health and perception of services from the perspective of children, adolescents and their families. Retrieved on
November 10, 2008, from http://www.forschungs portal.ch/unizh/p6202.htm

Morais, C. A., Amparo, D. M., Fukuda, C. C., \& Brasil, K. T. (2012). Concepções de saúde e doença mental na perspectiva de jovens brasileiros. Estudos de Psicologia (Natal), 17(3), 369-379. http://dx.doi.org/10.1590/S14 13-294X2012000300004

Owens, P. L., Hoagwood, K., Horwitz, S. J., Leaf, P., Poduska, J. M., Kellam, S. G., \& lalongo, N. S. (2002). Barriers to children's mental health services. Journal of the American Academy of Child and Adolescent Psychiatry, 41(6), 731-738.

Pasquali, L. (2012). Análise fatorial para pesquisadores. Brasília: Labpam.

Pinto, A. C. S., Luna, I. T., Silva, A. A., Pinheiro, P. N. C., Braga, V. A. B., \& Souza, A. M. A. (2014). Fatores de risco associados a problemas de saúde mental em adolescentes: revisão integrativa. Revista da Escola de Enfermagem USP, 48(3), 555-564. http://dx.doi.org/ 10.1590/S0080-623420140000300022

Programa das Nações Unidas para o Desenvolvimento. (2010). Relatório de Desenvolvimento Humano Brasileiro 2009/2010. Brasília: Autor.

Ramires, V. R. R., Passarini, D. S., Flores, G. G., \& Santos, L. G. (2009). Fatores de risco e problemas de saúde mental de crianças. Arquivos Brasileiros de Psicologia, 61(2), 1-14.

Reichenheim, M. E., \& Moraes, C. L. (2007). Operacionalização de adaptação transcultural de instrumentos de aferição usados em epidemiologia. Revista de Saúde Pública, 41(4), 665-673.

Santos, P. L. (2006). Problemas de saúde mental de crianças e adolescentes atendidos em um serviço público de Psicologia infantil. Psicologia em Estudo, 11(2), 315-321.

Simões, C. H. D., Fernandes, R. A., \& Aiello-Vaisberg, T. M. J. (2013). O profissional de saúde mental na reforma psiquiátrica. Estudos de Psicologia (Campinas), 30(2), 275-282. http://dx.doi.org/10.1590/s0103-16 6X2013000200014

World Health Organization. (2005). Atlas: Child and adolescent mental health resources: Global concerns, implications for the future. Geneva: Author.

Received: November 2, 2013

Final version: March 9, 2015

Approved: March 24, 2015 
